\title{
Reconstituting Breast Tissue with Organotypic Three-dimensional Co-culture of Epithelial and Stromal Cells in Discontinuous Extracellular Matrices
}

Gang Ren, Vandana Sharma, Joshua Letson, Yashna Walia, Veani Fernando and Saori Furuta*

Department of Cancer Biology, College of Medicine and Life Sciences, University of Toledo Health Science Campus, 3000 Arlington Ave. Toledo, $\mathrm{OH}$ 43614, USA

*For correspondence: Saori.Furuta@utoledo.edu

[Abstract] Co-culture systems utilizing reconstituted or synthetic extracellular matrix (ECM) and micropatterning techniques have enabled the reconstruction of surface epithelial tissues. This technique has been utilized in the regeneration, disease modeling and drug screening of the surface epithelia, such as the skin and esophagus. On the other hand, the reconstruction of glandular epithelia would require more intricate ECM organizations. Here we describe a protocol for a novel three-dimensional organotypic co-culture system for the reconstruction of mammary glands that utilizes the discontinuous ECM. In this technique, primary mammary fibroblasts first establish a layer of the connective tissue rich in collagen I. Then, mammary epithelial cells form acinar structures, the functional glandular units, within the laminin-rich basement membrane embedded in the connective tissue. This method allows for the regeneration of the in vivo-like architecture of mammary glands and could be utilized for monitoring the real-time response of mammary glands to drug treatment.

Keywords: ECM, Organotypic 3D co-culture, Glandular epithelia, Mammary gland, Cell culture stamp

[Background] Three-dimensional (3D) co-culturing of cells in the extracellular matrix (ECM) substratum allows for the reconstruction of the in vivo-like tissue architecture and behavior, as well as the analysis of cellular interactions within the tissue microenvironment (Langhans, 2018). Furthermore, the advent of synthetic ECM materials and micropatterning techniques in the 2000s has enabled the regeneration of optimal ECM composition and spatial orientation for each tissue type in co-culture (Hotary et al., 2000; Gudjonsson et al., 2002; Carey et al., 2017). In these 3D co-culture systems, fibroblasts form a layer of the connective tissue while epithelial cells grow on top of the connective tissue or on the plastic surfaces exposed by micropatterning the ECM ( Stark et al., 2004; Kalabis et al., 2012; March et al., 2015). This method enables the reconstruction of 3D architecture of surface (stratified) epithelia, such as skin and esophagus. Such 3D co-culture technique has been utilized in generation of the transplantable skin organoids (Kim et al., 2018), disease modeling (e.g., psoriasis, esophagitis) and drug screening (Klicks et al., 2017; Whelan et al., 2018; Sarkiri et al., 2019). On the other hand, this technique is not suitable for the reconstruction of glandular epithelia that have more intricate ECM organizations. The glandular epithelium is enclosed by the basement membrane, which is, in turn, embedded in the connective tissue encompassing fibroblasts and other stromal cells.

Here we introduce a novel 3D organotypic ECM co-culture technique for reconstructing the 3D 
structure of the mammary gland. Mammary epithelial cells and mammary fibroblasts are individually cultured in the discrete, physiologically-relevant ECM. The discontinuous ECM is generated by micropatterning the fibroblast-containing collagen I-rich matrix and filling the grooves with the epithelial cell-containing laminin-rich basement membrane. This organotypic 3D ECM co-culture system allows for the growth of epithelial and stromal cells in the distinct locales, serving as a robust in vitro technique for modeling diseases and testing drug efficacy.

\section{Materials and Reagents}

\section{A. Materials}

\section{Flasks, plates and insert}

1. T-75 flasks, vent (Corning, catalog number: 08-772-1F)

2. Corning Cell Culture 12 well plates (Corning, catalog number: 07-200-82)

3. Corning $12 \mathrm{~mm}$ Transwell with $3.0 \mu \mathrm{m}$ Pore Polycarbonate Membrane Insert (Corning, catalog number: 07-200-157)

\section{Histology}

1. Bio-wraps (Leica Biosystems, catalog number: 3801090)

2. Tissue and Biopsy Cassettes (Fisher Scientific, catalog number: 15-200-403J)

\section{Tools for Constructing a Custom Stamp}

1. 5-minute epoxy (JB Weld, ClearWeld \# 50112, Home Depot)

2. Round wooden disks ( $25 \mathrm{~mm}$ in diameter, $3 \mathrm{~mm}$ in thickness, Hobby Lobby)

3. Standard $2 \mathrm{~mm}$ drill bit

4. Standard $5 \mathrm{~mm}$ drill bit

B. Cells

1. Primary human mammary epithelial cells (ScienCell, catalog number: 7610)

2. MCF10A human mammary epithelial cells (Barbara Ann Karmanos Cancer Institute)

3. HMT-3522-S1 human mammary epithelial cells (Mina Bissell Laboratory, Lawrence Berkeley National Laboratory, Berkeley, CA)

4. Primary human mammary fibroblasts (ScienCell, catalog number: 7630)

C. Media

\section{For primary mammary epithelial cells}

1. Mammary Epithelial Cell Medium (MEpiCM, ScienCell, catalog number: 7611) supplemented with 1\% Mammary Epithelial Cell Growth Supplement (MEpiCGS, catalog number: 7652) and $1 \%$ penicillin/ streptomycin (Thermo Fisher, catalog number: $\mathrm{MT} 30002 \mathrm{Cl}$ ) 


\section{For MCF10A human mammary epithelial cells}

1. DMEM/F12 (Thermo Fisher, catalog number: 11320033) supplemented with the MCF10A additives (Recipe 1) (Debnath et al., 2003)

\section{For HMT-3522-S1 human mammary epithelial cells}

1. DMEM/F12 (Thermo Fisher, catalog number: 11320033) supplemented with the HMT-3522-S1 additives (Recipe 2) (Vidi et al., 2013)

\section{For primary human mammary fibroblasts}

1. Fibroblast Medium (FM, ScienCell, catalog number: 2301) supplemented with $1 \%$ Fibroblast Growth Supplement (FGS, catalog number: 2352) and 1\% penicillin/streptomycin

D. Reagents

\section{Reagents for culturing}

1. $0.05 \%$ trypsin/EDTA solution (Fisher Scientific, catalog number: $25-300-062$ )

2. $0.25 \%$ trypsin/EDTA solution (Fisher Scientific, catalog number: $15-050-057$ )

3. Soybean trypsin inhibitor (10 mg/ml, Thermo Fisher, catalog number: $17075-029)$

4. Dispase I (2mg [20U] Sigma-Aldrich, catalog number: D4818)

5. 0.5 M EDTA, pH 8.0 (Thermo Fisher, catalog number: AM9260G)

6. PBS (Thermo Fisher, catalog number: $\mathrm{SH} 3037803$ )

7. EGF (Sigma-Aldrich, catalog number: E-9644)

8. Hydrocortisone (Sigma-Aldrich, catalog number: $\mathrm{H}-0888$ )

9. Cholera toxin (Sigma-Aldrich, catalog number: C-8052)

10. Horse serum (Thermo Fisher, catalog number: 16050122)

11. Prolactin (Sigma-Aldrich, catalog number: L6520)

12. $\beta$-estradiol (Sigma-Aldrich, catalog number: C-8052)

13. Sodium selenite (Sigma-Aldrich, catalog number: $214485-5 G$ )

14. Transferrin (Sigma-Aldrich, catalog number: T2252)

15. HMT-3522-S1 additives (see Recipes)

16. MCF10A additives (see Recipes)

17. Phosphate buffered saline (PBS) (see Recipes)

18. Acellular layer matrix (see Recipes)

19. Cellular layer matrix (see Recipes)

20. Paraformaldehyde (see Recipes)

\section{Reagents for ECM}

1. Matrigel ( $\sim 10 \mathrm{mg} / \mathrm{ml}$, growth factor reduced, Corning, catalog number: 354230$)$

2. Corning Collagen I, Rat Tail (3-4 mg/ml, Corning, catalog number: CB-40236)

3. DMEM/F12 (10x), made from powder (Thermo Fisher, catalog number: 12500062) 
4. Sodium Bicarbonate $7.5 \%$ solution (50x, Thermo Fisher, catalog number: 25080094 )

5. FBS (JR Scientific, catalog number: 43603-500 [Research grade])

6. L-Glutamine (200 mM [50x], Thermo Fisher catalog number: 25030081)

\section{Reagents for Histology}

1. Paraformaldehyde (Sigma-Aldrich, catalog number: P6148-500G)

\section{Equipment}

1. Hand drill (De Walt, model: \#dcd7916 20v 1/2" chuck, Home Depot)

2. Stainless steel rods (Uxcell, $30 \mathrm{~mm} \times 2.5 \mathrm{~mm}$, Amazon.com)

3. 4" cast iron drill press vice (Irwin, model: \#226340, Home Depot)

4. $37^{\circ} \mathrm{C}$ water bath

5. $37^{\circ} \mathrm{C}$ humidified incubator with $5 \% \mathrm{CO}_{2}$

6. Cell culture benchtop centrifuge

7. Hemocytometer

8. Micropipettes (P20, P200 and P1000)

9. Pipette aid

10. Microscope with a color CCD camera

\section{Procedure}

A. Cell culture and maintenance

\section{Primary Human Mammary Epithelial cells}

Primary human mammary epithelial cells (ScienCell) were isolated from human breast and cryopreserved at passage one.

1. Prepare a poly-L-lysine $\left(2 \mu \mathrm{g} / \mathrm{cm}^{2}\right)$-coated T-75 flask. To obtain a $2 \mu \mathrm{g} / \mathrm{cm}^{2}$ poly-L-lysine-coated culture vessel, add $10 \mathrm{ml}$ of sterile water to a T-75 flask and then add $15 \mu$ l of poly-L-lysine stock solution $(10 \mathrm{mg} / \mathrm{ml})$. Leave the flask in a $37^{\circ} \mathrm{C}$ incubator overnight. Rinse the flask.

2. Thaw a frozen vial of cells ( $>5 \times 10^{5}$ cells) in a $37^{\circ} \mathrm{C}$ water bath, and dispense the contents of the vial into the poly-L-lysine-coated flask.

Note: Dilution and centrifugation of cells after thawing are not recommended.

3. Gently rock the flask to distribute cells evenly. Return the culture vessel to the incubator, and leave the culture undisturbed for at least $16 \mathrm{~h}$ after initiation.

4. Replace medium the next day to remove residual DMSO and unattached cells.

5. Thereafter, change the medium every three days, until the culture is approximately $70 \%$ confluent. Once the culture reaches $70 \%$ confluence, change the medium every other day until the culture is approximately $90 \%$ confluent.

6. Subculture when cells reach $90 \%$ confluence. Gently rinse the flask with PBS and add $4 \mathrm{ml} 0.25 \%$ 
Trypsin/EDTA solution into the flask. Gently rock the flask to ensure complete coverage of cells by Trypsin/EDTA solution, return the flask to the $37^{\circ} \mathrm{C}$ incubator and incubate it for $2-3$ min or until cells have detached.

7. After cells have completely detached from the flask, add $180 \mu \mathrm{l}$ of soybean trypsin inhibitor to the flask and transfer detached cells to a $15 \mathrm{ml}$ centrifuge tube.

8. Centrifuge the tube at $400 \times g$ for $5 \mathrm{~min}$ and discard the supernatant. Resuspend the cell pellet in culture medium and plate them in new poly-L-lysine-coated flasks at the seeding density of 5,000 cells $/ \mathrm{cm}^{2}$.

9. Cells can undergo ten population doublings (early passages are recommended).

\section{MCF10A Human Mammary Epithelial cells}

MCF10A cells were collected from human fibrocystic breast tissue and went through spontaneous immortalization. MCF10A cells maintain many characteristics of normal cells, including (a) the inability to form tumors in nude mice; (b) dependence on growth factors and hormones for growth and survival; and (c) lack of anchorage-independent growth (Soule et al., 1990). Culturing of MCF10A cells follows the protocol described by Debnath et al. (2003) with slight modifications.

1. Thaw a frozen vial of cells $\left(1 \times 10^{6} \mathrm{cells}\right)$ in a $37^{\circ} \mathrm{C}$ water bath and dispense the contents of the vial into a T-75 flask containing $10 \mathrm{ml}$ culture medium.

2. Gently rock the flask to distribute cells evenly. Return the culture vessel to the incubator and leave the culture undisturbed for at least $16 \mathrm{~h}$ after initiation.

3. Replace medium the next day to remove residual DMSO and unattached cells.

4. Change the medium every three days until the culture is approximately $70 \%$ confluent. Once cells reach $70 \%$ confluence, change the medium every other day until the culture is approximately $90 \%$ confluent.

5. Subculture when cells reach $90 \%$ confluence. Gently rinse the flask with PBS and add $4 \mathrm{ml} 0.25 \%$ Trypsin/EDTA solution into flask. Gently rock the flask to ensure complete coverage of cells by Trypsin/EDTA solution, return the flask to the $37^{\circ} \mathrm{C}$ incubator and incubate it for 2-3 min or cells have completely detached.

6. Add $180 \mu \mathrm{l}$ of soybean trypsin inhibitor to the flask and transfer detached cells to a $15 \mathrm{ml}$ centrifuge tube.

7. Centrifuge the tube at $400 \times g$ for $5 \mathrm{~min}$ and discard the supernatant. Resuspend cell pellets in culture medium and plate them in new flasks at a 1:3 ratio.

8. Cells can undergo 35 passages (early passages are recommended).

\section{HMT-3522 S1 Human Mammary Epithelial cells}

HMT-3522 S1 was derived from a benign mammary fibrocystic lesion and became spontaneously immortalized in culture (Briand et al., 1987; Moyret et al., 1994; Rizki et al., 2008; Vidi et al., 2013). S1 cells retain non-malignant characteristics, requiring EGF to grow in culture and being unable to form tumors in nude mice (Briand et al., 1987; Rizki et al., 2008; Vidi et al., 2013). 
Note: The use of $\mathrm{S} 1$ cells is restricted to passages below 60 because of genotypic drift at higher passages (Rizki et al., 2008; Vidi et al., 2013). Culturing of HMT-3522 S1 cells follows the protocol described by Vidi et al. (2013) with slight modifications.

1. Thaw a frozen vial of cells $\left(1 \times 10^{6}\right.$ cells $)$ in a $37^{\circ} \mathrm{C}$ water bath, and dispense the contents of the vial into a centrifuge tube with $5 \mathrm{ml}$ of growth medium.

2. Centrifuge the tube at $400 \times g$ for $5 \mathrm{~min}$.

3. Remove the supernatant and resuspend the cell pellet in $3 \mathrm{ml}$ of fresh growth medium.

4. Add $7 \mathrm{ml}$ fresh growth medium into a T-75 flask and transfer the whole cell suspension.

5. Return the culture vessel to the incubator and leave the culture undisturbed for two days after initiation.

6. Change the medium every other day until colonies start forming rounded islands (the edges of the colonies become smooth).

Note: This phenomenon usually takes place when the culture reaches $\sim 60 \%$ confluence $(6 \sim 10$ days after plating).

7. Subculture when cells reach $60 \%$ confluence. Rinse the cells with $1 \mathrm{ml} 0.25 \%$ Trypsin/EDTA solution and add $1 \mathrm{ml} 0.25 \%$ Trypsin/EDTA solution into the flask. Gently rock the flask to ensure complete coverage of cells by Trypsin/EDTA solution, return the flask to the incubator and incubate it at $37^{\circ} \mathrm{C}$ for $2-3 \mathrm{~min}$.

8. Add $180 \mu \mathrm{l}$ of soybean trypsin inhibitor to the flask and transfer detached cells to a $15 \mathrm{ml}$ centrifuge tube.

9. Centrifuge the tube at $400 \times \mathrm{g}$ for $5 \mathrm{~min}$ and then discard the supernatant.

10. Resuspend cells in $3 \mathrm{ml}$ culture medium and count cell density.

11. Place $10 \mathrm{ml}$ growth medium into a T-75 flask.

12. Seed $1.5 \times 10^{6}$ cells in a T-75 flask $\left(2 \times 10^{4}\right.$ cells $\left./ \mathrm{cm}^{2}\right)$.

13. Cells can be used until 60 passages (early passages are recommended).

\section{Primary Human Mammary Fibroblasts}

Primary human mammary fibroblasts (ScienCell) were isolated from human breast and cryopreserved at passage one.

1. Prepare a poly-L-lysine $\left(2 \mu \mathrm{g} / \mathrm{cm}^{2}\right)$-coated T-75 flask as mentioned above.

2. Thaw a frozen vial of cells ( $>5 \times 10^{5}$ cells) in a $37^{\circ} \mathrm{C}$ water bath, and dispense the contents of the vial into the poly-L-lysine-coated flask. Gently rock the flask to distribute cells evenly. Return the culture vessel to the incubator and leave the culture undisturbed for at least $16 \mathrm{~h}$ after initiation.

3. Replace medium the next day to remove residual DMSO and unattached cells.

4. Change the medium every three days thereafter, until the culture is approximately $70 \%$ confluent. Once cells reach $70 \%$ confluence, change the medium every other day until the culture is approximately $90 \%$ confluent. 
5. Subculture when cells reach $90 \%$ confluence. Rinse the cells with PBS and add $10 \mathrm{ml}$ of $0.05 \%$ Trypsin/EDTA solution into flask. Gently rock the flask to ensure complete coverage of cells by Trypsin/EDTA solution, return the flask to the incubator and incubate it at $37^{\circ} \mathrm{C}$ for $2-3 \mathrm{~min}$. Add $180 \mu \mathrm{l}$ of soybean trypsin inhibitor to the flask and transfer detached cells to a $15 \mathrm{ml}$ centrifuge tube.

6. Centrifuge the tube at $400 \times g$ for 5 min and discard the supernatant. Resuspend the cells in culture medium and plate them in new poly-L-lysine-coated flasks at the seeding density of 5,000 cells $/ \mathrm{cm}^{2}$.

7. Cells can undergo 15 population doublings.

B. Construction of a micropatterning stamp (Figure 1)
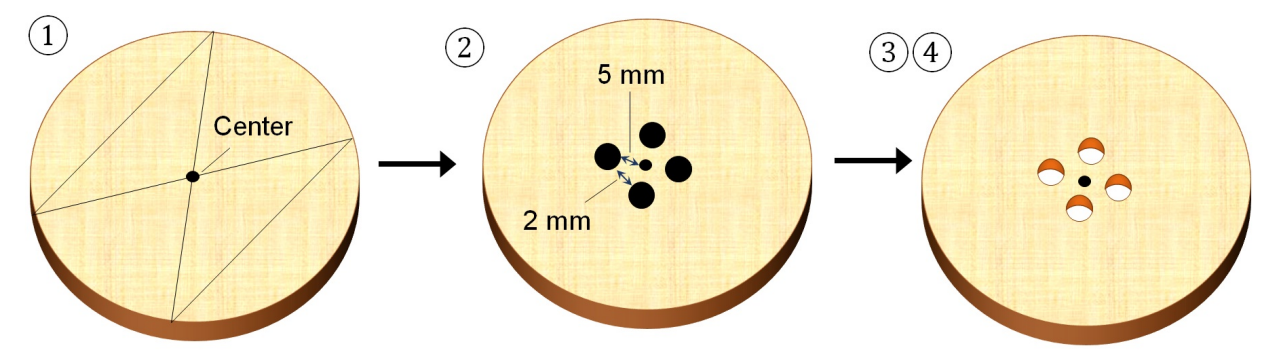

(9) (10)
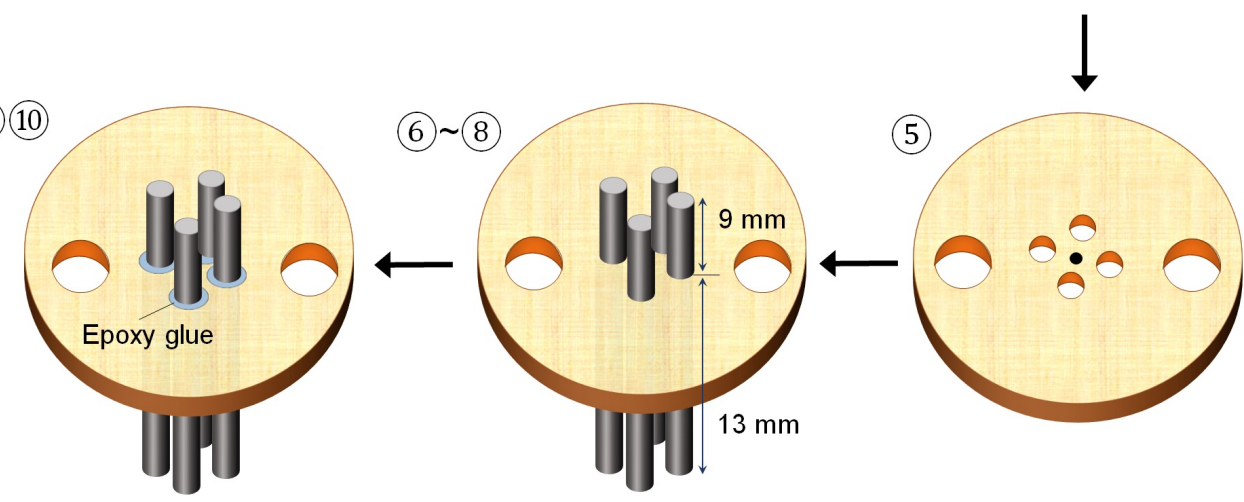

(6) (8)

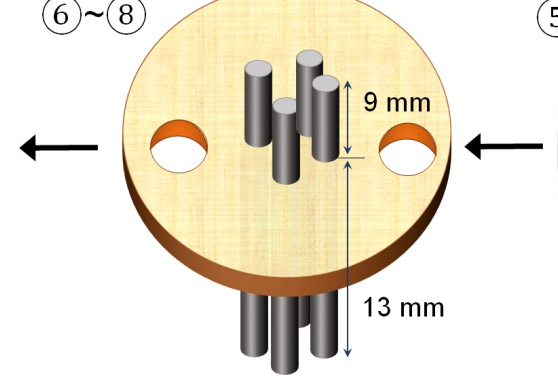

(5)

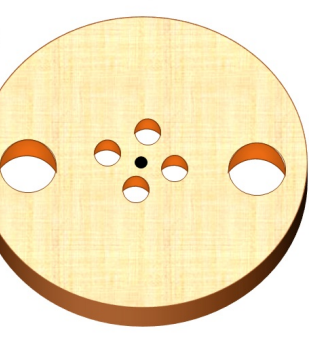

Figure 1. Construction of micropatterning stamp

A custom stamp for micropatterning the ECM in a 12-well plate insert is constructed as follows:

1. To find the center of a round wooden disk, draw two parallel chords with equal length across the circle with a pencil. Draw an " $X$ " that links the ends of the chords diagonally. Mark the intersection of the " $X$ " as the center of the circle.

2. Using a pencil, mark four $2 \mathrm{~mm}$-spots on the disk at $5 \mathrm{~mm}$ from the center, $2 \mathrm{~mm}$ apart from each other.

3. Secure the disk horizontally in a drill press vice.

4. Using a hand drill in conjunction with $2 \mathrm{~mm}$-drill bit, drill four holes through the spots marked on the disk.

5. Using a hand drill in conjunction with $5 \mathrm{~mm}$-drill bit, drill two access holes on the opposite ends of the disk. 
6. Remove the disk from the drill press vice.

7. Insert 2.5-mm stainless steel rods into the $2 \mathrm{~mm}$-holes on the disk. This provides a press fit for rods to hold them in place until they are secured with epoxy.

8. Adjust the rods so that the $9 \mathrm{~mm}$-ends of the rods remain above the top surface of the disk and $13 \mathrm{~mm}$-ends of the rods protrude from the bottom surface of the disk.

9. Mix and apply a small amount of epoxy to the perimeter of the rods on the top side of the disk where they meet the disk to secure them in place. Air-dry the stamp as recommended on the package of the epoxy.

10. Clean the metal rods of the stamp lightly with $70 \%$ alcohol, and UV-irradiate the stamp for 10 $20 \mathrm{~min}$ in a tissue culture hood for sterilization before use.

C. Preparation of 3D organotypic co-culture (Figure 2)

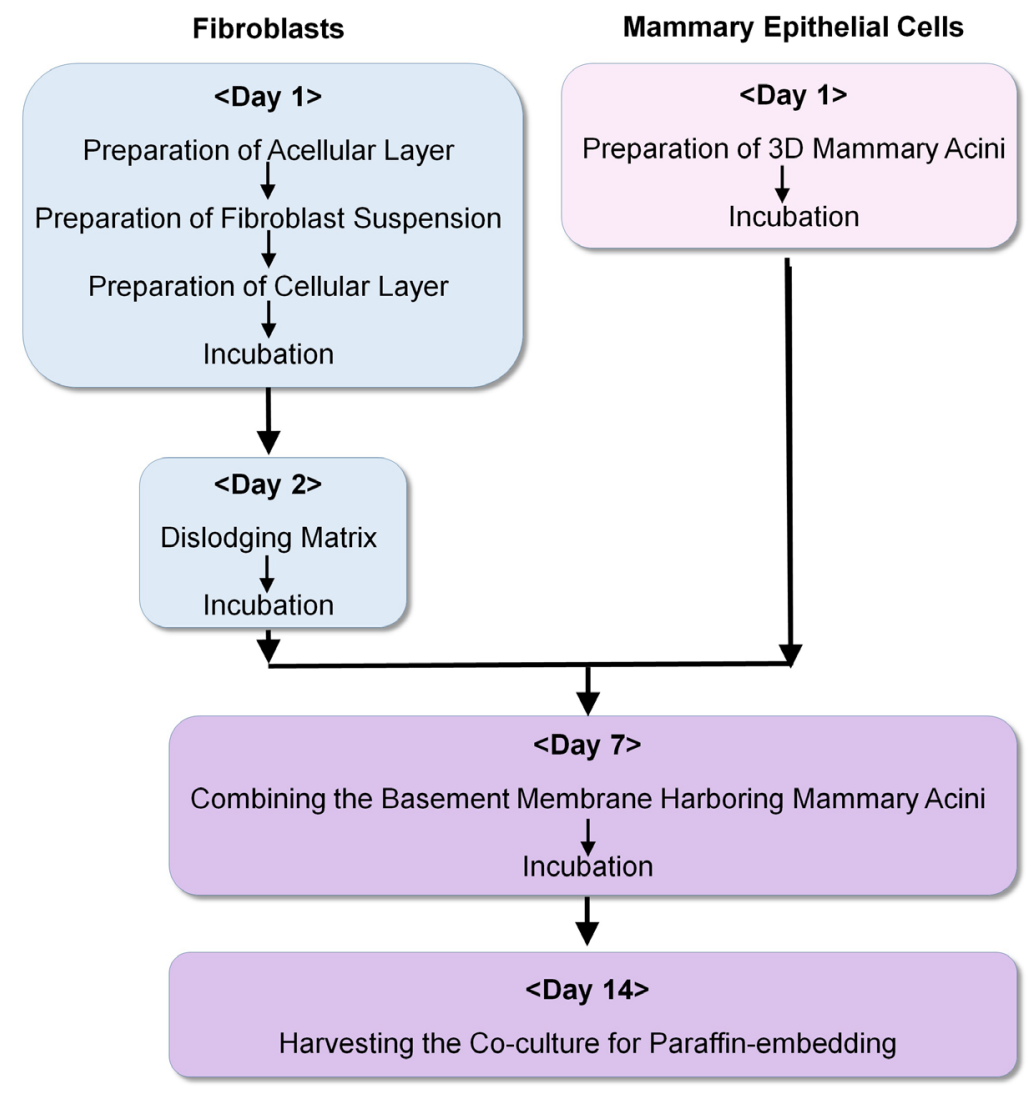

Figure 2. Flow Chart of 3D Organotypic Co-culture of mammary epithelial cells and fibroblasts

\section{Day 1}

1. Preparation of acellular layer

a. Prepare a 12-well plate.

b. Place a transwell insert into each well.

c. Adjust the concentration of type I collagen to $2 \mathrm{mg} / \mathrm{ml}$ in PBS and the $\mathrm{pH}$ to 7.4 with sterile 
$1 \mathrm{M} \mathrm{NaOH}$.

d. To make the acellular layer, add 10x DMEM/F12, FBS, L-Glutamine, N-bicarbonate and type I collagen $(2 \mathrm{mg} / \mathrm{ml})$ in this order into a centrifuge tube on ice (Recipe 4$)$.

e. Mix gently and readjust the $\mathrm{pH}$ to 7.4 with sterile $1 \mathrm{M} \mathrm{NaOH}$.

f. Place $200 \mu$ l of gel into each insert.

g. Leave the plate undisturbed at room temperature in a tissue culture hood for 30 min during polymerization of collagen.

2. Preparation of fibroblast suspension

a. Grow primary mammary fibroblasts in three T-175 flasks.

b. Trypsinize and combine all dissociated cells in a $50 \mathrm{ml}$ centrifuge tube.

c. Centrifuge, wash and resuspend the pellet in $1 \mathrm{ml}$ of fibroblast growth medium.

d. Count the cell density and adjust it to $1 \times 10^{8} / \mathrm{ml}$ with fibroblast medium.

3. Preparation of cellular layer

a. Adjust the concentration of type I collagen to $2 \mathrm{mg} / \mathrm{ml}$ in PBS and the $\mathrm{pH}$ to 7.4 with sterile $1 \mathrm{M} \mathrm{NaOH}$.

b. Add 10x DMEM/F12, FBS, L-Glutamine, $\mathrm{N}$-bicarbonate and type I collagen $(2 \mathrm{mg} / \mathrm{ml})$ in this order into a centrifuge tube on ice (Recipe 4).

c. Mix gently and adjust the $\mathrm{pH}$ to 7.4 with sterile $1 \mathrm{M} \mathrm{NaOH}$.

d. Add Matrigel and fibroblasts.

e. Place $1.0 \mathrm{ml}$ gel into each insert ( $1 \times 10^{7}$ fibroblasts $/$ sample).

f. Place a custom stamp into the gel (Figure 3, top left)

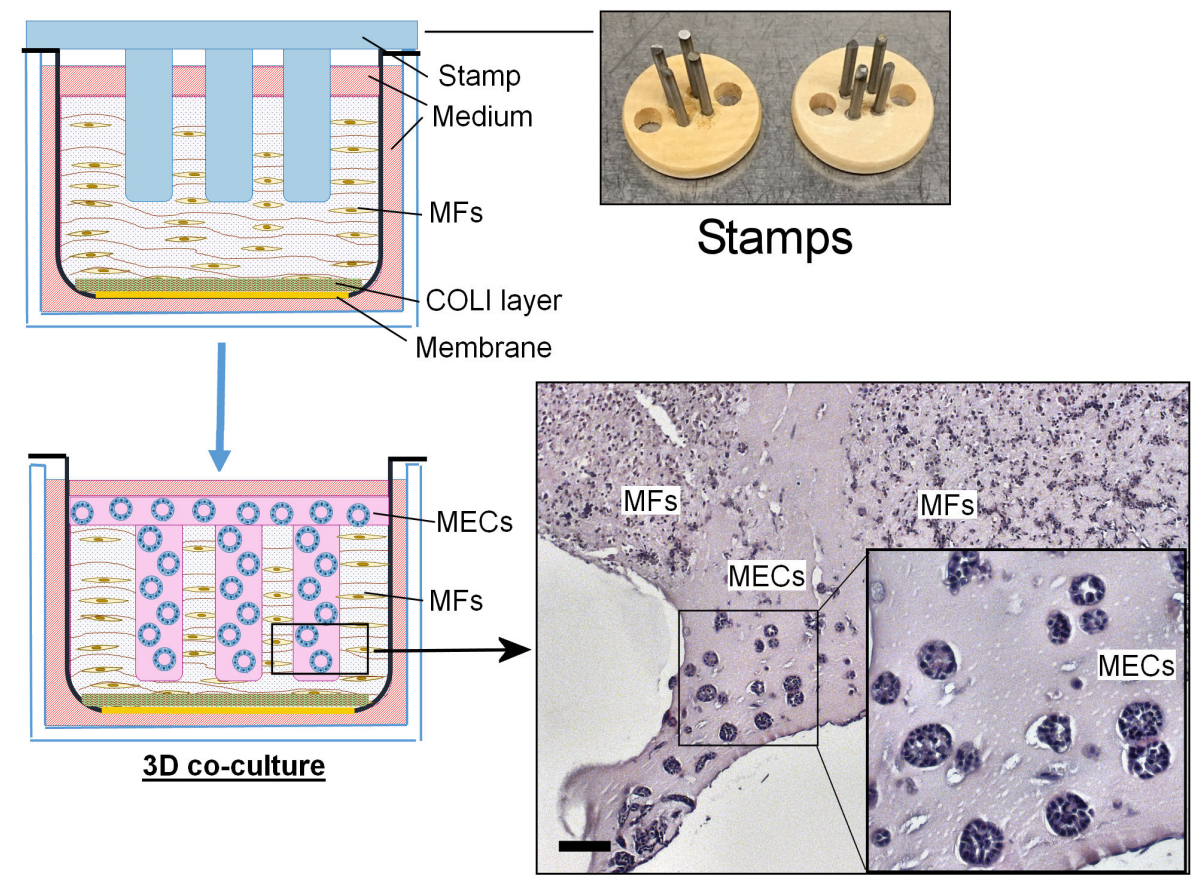

H\&E

Figure 3. Scheme of organotypic 3D ECM co-culture of primary mammary fibroblasts 
(MFs) and mammary epithelial cells (MECs). (Left) Schematic representation of experimental design of organotypic 3D ECM co-culture, where MECs and MFs are grown in distinct locales of the discontinuous ECM with the help of a micropatterning stamp on top of Collagen I matrix. (Right top) Image of the custom-made stamps. (Right bottom) Representative image of Hematoxylin and Eosin stained paraffin-embedded section of a co-culture showing the histomorphology of MFs and MECs at 40x and 200x magnifications. Scale bar: $50 \mu \mathrm{m}$.

g. Leave the plate undisturbed for $30-45 \mathrm{~min}$ in the tissue culture incubator $\left(37^{\circ} \mathrm{C}, 5 \% \mathrm{CO}_{2}\right)$ during polymerization of the matrix.

h. Add the fibroblast growth medium through the access holes of the stamp, $\sim 4 \mathrm{ml}$ into the bottom of the wells and $\sim 1 \mathrm{ml}$ into the insert.

i. Leave the plate in the tissue culture incubator $\left(37^{\circ} \mathrm{C}, 5 \% \mathrm{CO}_{2}\right)$ for one day until the matrix is manually dislodged from the inner wall of the insert.

4. Preparation of 3D mammary acini

\section{Matrigel Coating and Matrigel Suspension}

a. Thaw Matrigel at $4{ }^{\circ} \mathrm{C}$ overnight and keep it on ice.

b. Coat a 12-well culture plate with $\sim 500 \mu \mathrm{l}$ Matrigel per well. Incubate for $15-30 \mathrm{~min}$ in a $37^{\circ} \mathrm{C}$ tissue culture incubator to allow polymerization of Matrigel.

c. In a $15 \mathrm{ml}$ centrifuge tube, prepare $4 \%$ Matrigel suspension in the mammary epithelial cell growth medium.

\section{Preparation of Mammary Acini}

Note: Normal or non-malignant mammary epithelial cells form mammary acinar-like structures)

a. Trypsinize, wash and resuspend mammary epithelial cells (primary mammary epithelial cells, MCF10A cells or HMT-3522 S1 cells) in $1 \mathrm{ml}$ mammary epithelial cell growth medium.

b. Count the cell density and transfer the volume of the cell suspension to have $1 \times 10^{5}$ cells $/ \mathrm{sample}$ in each well of a 12 well plate $\left(0.26 \times 10^{5} \mathrm{cells} / \mathrm{cm}^{2}\right)$.

c. Centrifuge to collect the cell pellet, and resuspend cells in $1 \mathrm{ml} 4 \%$ Matrigel suspension per sample.

d. Place the cell suspension onto Matrigel coat.

e. Leave the plate in the tissue culture incubator $\left(37^{\circ} \mathrm{C}, 5 \% \mathrm{CO}_{2}\right)$ for six days until spheroid structures are formed.

\section{Day 2}

5. Dislodging collagen 1 (Acellular and Cellular) matrix (Figure 4)

a. Carefully lift up and remove the stamp from the co-culture.

b. Remove the growth medium.

c. Using a sterile glass Pasteur pipette, outline the circumference of the matrix for 2-3 times 
to dislodge the matrix from the inner wall of the insert.

Note: Do not pierce the transwell membrane.

d. Place the stamp back to fit into the grooves.

e. Add $1 \mathrm{ml}$ fibroblast growth medium into the insert.

f. Leave the plate in the tissue culture incubator $\left(37^{\circ} \mathrm{C}, 5 \% \mathrm{CO}_{2}\right)$ for five days. The matrix will become contracted over the next few days. The medium in the bottom of the well is replaced daily (no change of the medium in the insert).

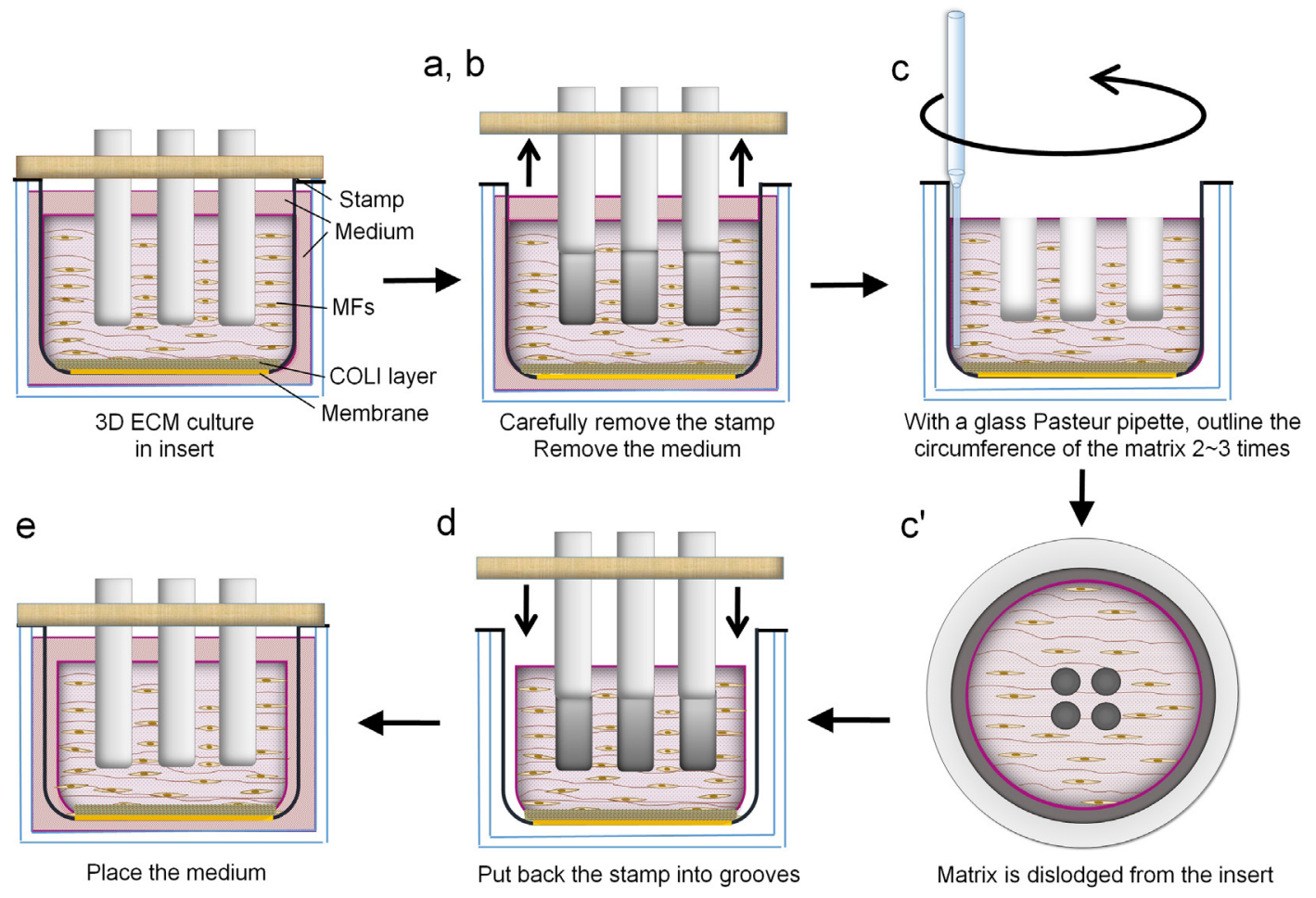

Figure 4. Dislodging collagen I (COL1, acellular and cellular) matrix

\section{Day 7}

6. Combining the basement membrane harboring mammary acini

\section{Dissociation of Mammary Acini from Matrigel}

a. Dissolve Dispase I ( $2 \mathrm{mg}, 20 \mathrm{U})$ in $200 \mu \mathrm{l}$ PBS to make the stock solution $(10 \mathrm{mg} / \mathrm{ml}, 100$ $\mathrm{U} / \mathrm{ml})$. Further dilute Dispase I solution to make the working solution $(0.2 \mathrm{mg} / \mathrm{ml}, 2 \mathrm{U} / \mathrm{ml})$.

b. Remove the Matrigel suspension from the mammary epithelial culture in the 3D matrix. Wash with PBS.

C. Add $1 \mathrm{ml}$ working solution of Dispase I $(2 \mathrm{U} / \mathrm{ml})$. Incubate for $30 \mathrm{~min}$ in a $37^{\circ} \mathrm{C}$ tissue culture incubator for enzymatic digestion of Matrigel.

d. Add $20 \mu \mathrm{l} 0.5 \mathrm{M}$ EDTA ( $\mathrm{pH} 8.0$, final concentration of $1 \mathrm{mM}$ ) to inactivate Dispase I.

e. Collect the digest in a $15 \mathrm{ml}$ centrifuge tube. Centrifuge and wash the cell pellet in PBS 2 3 times.

f. Resuspend the pellet $\left(\sim 2 \times 10^{4}\right.$ acini) in $500 \mu$ l Matrigel and keep it on ice 


\section{Addition of Mammary Acini in Matrigel to Collagen Matrix (Figure 5)}

a. Carefully remove the stamp.

b. Remove the growth medium from the insert.

C. Into four grooves formed after removing the stamp, transfer $\sim 100 \mu$ l/groove Matrigel/mammary acini mixture. Place the remaining mixture $(\sim 100 \mu \mathrm{l})$ on the surface of the cellular layer. Incubate for $30 \mathrm{~min}$ in a $37^{\circ} \mathrm{C}$ tissue culture incubator for polymerization of Matrigel (Figure 5).

d. Prepare fibroblast growth medium/mammary epithelial cell growth medium (50:50) mixture and add $\sim 4 \mathrm{ml}$ into the bottom of the wells and $\sim 1 \mathrm{ml}$ into the insert.

e. For the analysis of drug treatments, different drugs can be added to the growth medium.

f. Leave the plate in the tissue culture incubator $\left(37^{\circ} \mathrm{C}, 5 \% \mathrm{CO}_{2}\right)$ for seven days. Change the medium daily.

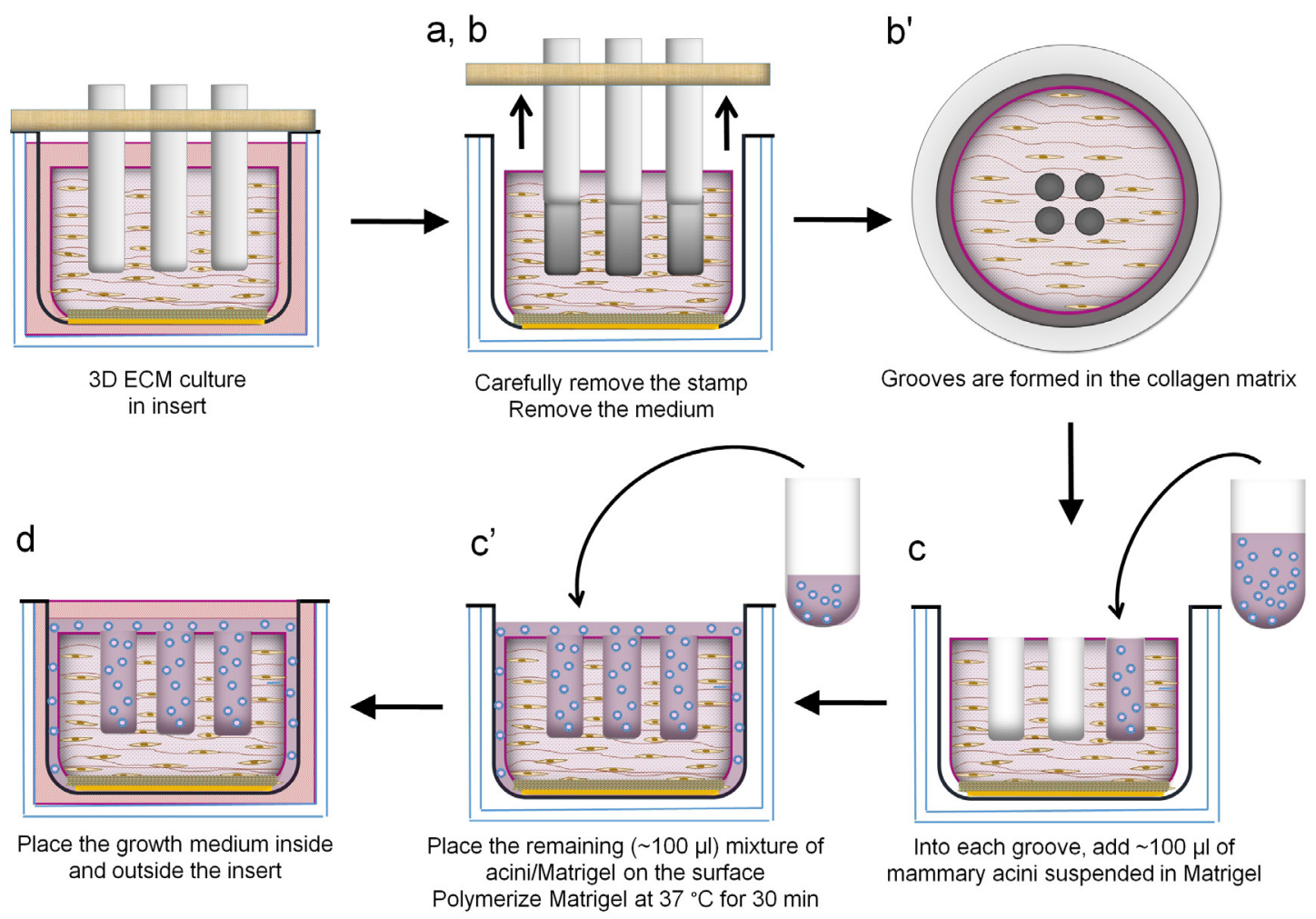

Figure 5. Adding mammary acini/Matrigel mixture to the collagen matrix

\section{Day 14}

7. Harvesting the co-culture for paraffin-embedding

a. Fix the co-cultures with $4 \%$ paraformaldehyde at $4{ }^{\circ} \mathrm{C}$ for $2 \sim 3 \mathrm{~h}$. Wash the cultures in PBS at RT for $10 \mathrm{~min}$.

Note: Do not fix for too long. Over fixation will destroy certain antigens.

b. Flip the insert and cut out the membrane. Gently push out the co-culture from the insert into the well plate. Add PBS to cover the culture. 
c. Place a Bio-Wrap inside a tissue cassette. Position the co-culture face-down on the BioWrap. Fold the Bio-Wrap to wrap the co-culture and close the cassette.

d. Put the cassettes in $70 \% \mathrm{EtOH}$ and keep at $4{ }^{\circ} \mathrm{C}$ until processing for paraffin-embedding.

e. Section paraffin-blocks at $10 \mu \mathrm{m}$ and analyze the sections by immunohistochemistry (Figure 3 , bottom right).

\section{$\underline{\text { Recipes }}$}

1. MCF10A additives

\section{Reagent}

Horse serum

Penicillin/streptomycin

Insulin

EGF

Hydrocortisone

Cholera toxin

\section{Final Concentration}

$5 \%$

$1 \%$

$10 \mu \mathrm{g} / \mathrm{ml}$

$20 \mathrm{ng} / \mathrm{ml}$

$0.5 \mu \mathrm{g} / \mathrm{ml}$

$100 \mathrm{ng} / \mathrm{ml}$

2. HMT-3522-S1 additives

$\begin{array}{ll}\text { Reagent } & \text { Final Con } \\ \text { Prolactin } & 5 \mu \mathrm{m} / \mathrm{ml} \\ \text { Insulin } & 250 \mathrm{ng} / \mathrm{ml} \\ \text { EGF } & 5 \mathrm{ng} / \mathrm{ml} \\ \text { Hydrocortisone } & 1.4 \mu \mathrm{M} \\ \beta \text {-estradiol } & 0.1 \mathrm{nM} \\ \text { Sodium selenite } & 2.6 \mathrm{ng} / \mathrm{ml} \\ \text { Transferrin } & 10 \mu \mathrm{g} / \mathrm{ml}\end{array}$

3. Phosphate buffered saline (PBS)

$\begin{array}{ll}\text { Reagent } & \text { Final Conce } \\ \mathrm{NaCl} & 137 \mathrm{mM} \\ \mathrm{KCl} & 2.7 \mathrm{mM} \\ \mathrm{Na}_{2} \mathrm{HPO}_{4} & 10 \mathrm{mM} \\ \mathrm{KH}_{2} \mathrm{PO}_{4} & 1.8 \mathrm{mM}\end{array}$

Adjust $\mathrm{pH}$ to 7.4 and autoclave to sterilize $\left(121^{\circ} \mathrm{C}, 15 \mathrm{~min}\right)$

Store PBS at $4{ }^{\circ} \mathrm{C}$

4. Acellular layer matrix (Final concentration of $1 \mathrm{mg} / \mathrm{ml}$ collagen, total $1.8 \mathrm{ml}$ for 6 samples)

$\begin{array}{ll}\text { Reagent } & \text { Volume } \\ \text { 10x DMEM/F12 } & 180 \mu \mathrm{l} \\ \text { FBS } & 18 \mu \mathrm{l} \\ \text { L-Glutamine } & 18 \mu \mathrm{l} \\ \text { Na-bicarbonate } & 18 \mu \mathrm{l}\end{array}$


Type I collagen $(2 \mathrm{mg} / \mathrm{ml}, \mathrm{pH} 7.4) \quad 900 \mu \mathrm{l}$

Sterile water

Up to $1.8 \mathrm{ml}$

Add in this order. Keep the mixture on ice until use. Mix gently and readjust the $\mathrm{pH}$ to 7.4 with sterile $1 \mathrm{M} \mathrm{NaOH}$

5. Cellular layer matrix (Final concentration of $\sim 1 \mathrm{mg} / \mathrm{ml}$ collagen $+\sim 3 \mathrm{mg} / \mathrm{ml}$ Matrigel, total $10 \mathrm{ml}$ for 6 samples)

\section{Reagent}

10x DMEM/F12

FBS

L-Glutamine

Na-bicarbonate

Type I collagen (2 mg/ml, $\mathrm{pH} 7.4)$

\section{Volume}

$1.0 \mathrm{ml}$

$100 \mu \mathrm{l}$

$100 \mu \mathrm{l}$

$100 \mu \mathrm{l}$

$5.0 \mathrm{ml}$

Readjust the $\mathrm{pH}$ to 7.4 with sterile $1 \mathrm{M} \mathrm{NaOH}$.

$\begin{array}{ll}\text { Matrigel } & 2.5 \mathrm{ml} \\ \text { Fibroblasts }\left(1 \times 10^{8} / \mathrm{ml}\right) & 1.0 \mathrm{ml} \\ \text { Sterile Water } & \text { Up to } 10 \mathrm{ml}\end{array}$

Add in this order. Keep the mixture on ice until use

6. Paraformaldehyde $(4 \%, 1 \mathrm{~L})$

a. Add $800 \mathrm{ml}$ of $1 \times$ PBS to a glass beaker on a stir plate and heat to $\sim 60^{\circ} \mathrm{C}$ while stirring

b. Add $40 \mathrm{~g}$ of paraformaldehyde powder and stir

c. Add $1 \mathrm{~N} \mathrm{NaOH}$ dropwise until the solution becomes clear

d. Once the paraformaldehyde is dissolved, cool down the solution to the room temperature

e. Recheck the $\mathrm{pH}$, and adjust it with $1 \mathrm{~N} \mathrm{HCl}$ or $\mathrm{NaOH}$ to $\sim \mathrm{pH} 6.9$

f. Adjust the volume of the solution to $1 \mathrm{~L}$ with $1 \times \mathrm{PBS}$

g. Store the solution at $2-8{ }^{\circ} \mathrm{C}$ for up to one month

\section{Acknowledgments}

We thank Robert Del Chiaro for constructing custom micropatterning stamps; Allen Schroering in the Histology Core, UT, and all the staffs in the Department of Pathology, UT, for preparation and evaluation of histological specimens. This work was supported by the startup fund from University of Toledo Health Science Campus, College of Medicine and Life Sciences, Department of Cancer Biology to S.F; Ohio Cancer Research Grant (Project \#: 5017) to S.F; Medical Research Society (Toledo Foundation) Award to S.F; and American Cancer Society Research Scholar Grant (RSG18-238-01-CSM) to S.F.

This protocol was adapted from Debnath et al. (2003) for the method to culture MCF10A cells; Vidi et al. (2013) for the method to culture HMT-3522 S1 cells; and modified from Kalabis et al. (2012) for the method of organotypic 3D culture. 
Please cite this article as: Ren et. al., (2019). Reconstituting Breast Tissue with Organotypic Three-dimensional Co-culture of Epithelial and Stromal Cells in Discontinuous Extracellular Matrices, Bio-protocol 9 (19): e3392. DOI: 10.21769/BioProtoc.3392.

\section{Competing interests}

The authors declare that the research was conducted in the absence of any commercial or financial relationships that could be construed as a potential conflict of interest.

\section{Ethics}

All animal experiments conformed to The Guide for the Care and Use of Laboratory Animals (National Research Council, National Academy Press, Washington, D.C., 2010) and were performed with the approval of the Institutional Animal Care and Use Committee of the University of Toledo, Toledo, $\mathrm{OH}$ (Protocol No: 108658).

\section{References}

1. Briand, P., Petersen, O. W. and Van Deurs, B. (1987). A new diploid nontumorigenic human breast epithelial cell line isolated and propagated in chemically defined medium. In Vitro Cell Dev Biol 23(3): 181-188.

2. Carey, S. P., Martin, K. E. and Reinhart-King, C. A. (2017). Three-dimensional collagen matrix induces a mechanosensitive invasive epithelial phenotype. Sci Rep 7: 42088.

3. Debnath, J., Muthuswamy, S. K. and Brugge, J. S. (2003). Morphogenesis and oncogenesis of MCF-10A mammary epithelial acini grown in three-dimensional basement membrane cultures. Methods 30(3): 256-268.

4. Gudjonsson, T., Rønnov-Jessen, L., Villadsen, R., Rank, F., Bissell, M.J. and Petersen, O.W. (2002). Normal and tumor-derived myoepithelial cells differ in their ability to interact with luminal breast epithelial cells for polarity and basement membrane deposition. J Cell Sci 115(Pt 1): 3950 .

5. Hotary, K., Allen, E., Punturieri, A., Yana, I. and Weiss, S. J. (2000). Regulation of cell invasion and morphogenesis in a three-dimensional type I collagen matrix by membrane-type matrix metalloproteinases 1, 2, and 3. J Cell Biol 149(6): 1309-1323.

6. Kalabis, J., Wong, G. S., Vega, M. E., Natsuizaka, M., Robertson, E. S., Herlyn, M., Nakagawa, H. and Rustgi, A. K. (2012). Isolation and characterization of mouse and human esophageal epithelial cells in 3D organotypic culture. Nat Protoc 7(2): 235-246.

7. Kim, Y., Park, N., Rim, Y. A., Nam, Y., Jung, H., Lee, K. and Ju, J. H. (2018). Establishment of a complex skin structure via layered co-culture of keratinocytes and fibroblasts derived from induced pluripotent stem cells. Stem Cell Res Ther 9(1): 217.

8. Klicks, J., von Molitor, E., Ertongur-Fauth, T., Rudolf, R. and Hafner, M. (2017). In vitro skin three-dimensional models and their applications. J Cell Biotech. 3(1): 21-39.

9. March, S., Ramanan, V., Trehan, K., Ng, S., Galstian, A., Gural, N., Scull, M. A., Shlomai, A., Mota, M. M., Fleming, H. E., Khetani, S. R., Rice, C. M. and Bhatia, S. N. (2015). Micropatterned 
Please cite this article as: Ren et. al., (2019). Reconstituting Breast Tissue with Organotypic Three-dimensional Co-culture of Epithelial and Stromal Cells

coculture of primary human hepatocytes and supportive cells for the study of hepatotropic pathogens. Nat Protoc 10(12): 2027-2053.

10. Moyret, C., Madsen, M. W., Cooke, J., Briand, P. and Theillet, C. (1994). Gradual selection of a cellular clone presenting a mutation at codon 179 of the p53 gene during establishment of the immortalized human breast epithelial cell line HMT-3522. Exp Cell Res 215(2): 380-385.

11. Rizki, A., Weaver, V. M., Lee, S. Y., Rozenberg, G. I., Chin, K., Myers, C. A., Bascom, J. L., Mott, J. D., Semeiks, J. R., Grate, L. R., Mian, I. S., Borowsky, A. D., Jensen, R. A., Idowu, M. O., Chen, F., Chen, D. J., Petersen, O. W., Gray, J. W. and Bissell, M. J. (2008). A human breast cell model of preinvasive to invasive transition. Cancer Res 68(5): 1378-1387.

12. Sarkiri, M., Fox, S. C., Fratila-Apachitei, L. E. and Zadpoor, A. A. (2019). Bioengineered skin intended for skin disease modeling. Int J Mol Sci 20(6).

13. Soule, H. D., Maloney, T. M., Wolman, S. R., Peterson, W. D., Jr., Brenz, R., McGrath, C. M., Russo, J., Pauley, R. J., Jones, R. F. and Brooks, S. C. (1990). Isolation and characterization of a spontaneously immortalized human breast epithelial cell line, MCF-10. Cancer Res 50(18): 6075-6086.

14. Stark, H. J., Willhauck, M. J., Mirancea, N., Boehnke, K., Nord, I., Breitkreutz, D., Pavesio, A., Boukamp, P. and Fusenig, N. E. (2004). Authentic fibroblast matrix in dermal equivalents normalises epidermal histogenesis and dermoepidermal junction in organotypic co-culture. Eur J Cell Biol 83(11-12): 631-645.

15. Vidi, P. A., Bissell, M. J., and Lelièvre, S. A. (2013a). Three-dimensional culture of human breast epithelial cells: the how and the why. Methods Mol Biol. 945:193-219.

16. Whelan, K. A., Muir, A. B.and Nakagawa, H. (2018). Esophageal 3D culture systems as modeling tools in esophageal epithelial pathobiology and personalized medicine. Cell Mol Gastroenterol Hepatol 5(4): 461-478. 